\title{
Magnesium underpotential deposition from nitrate melts and alloy formation with platinum substrate
}

\author{
V. S. Cvetković ${ }^{1}$, J. N. Jovićević ${ }^{1 *}$, L. J. Bjelica ${ }^{2}$ \\ ${ }^{1}$ Institute of Chemistry, Technology and Metallurgy, Department of Electrochemistry, University of Belgrade, \\ Njegoševa 12, 11000 Belgrade, PAK 125213, Serbia \\ ${ }^{2}$ Faculty of Sciences and Mathematics, University of N. Sad, Trg Dositeja Obradovića 3, 21000 N. Sad, Serbia
}

Received 15 November 2015, received in revised form 3 December 2015, accepted 15 January 2016

\begin{abstract}
This paper investigates magnesium underpotential deposition on platinum electrodes from magnesium nitrate-ammonium nitrate melts at temperatures ranging from 400 to $500 \mathrm{~K}$. Electrochemical techniques used were linear sweep voltammetry and potential step. Electrode surfaces were studied by Scanning electron microscopy (SEM), Atomic force microscopy (AFM), Energy dispersive spectrometry (EDS), energy dispersive X-Ray spectroscopy (EDX) and XRay diffraction (XRD). In the underpotential range studied, it was found that magnesium underpotential deposition took part simultaneously with reduction processes of nitrate and nitrite. EDS and XRD measurements showed clear evidence of $\mathrm{MgPt}_{3}, \mathrm{Mg}_{3} \mathrm{Pt}$ alloys being formed.
\end{abstract}

K e y w or ds: magnesium/platinum alloys, underpotential deposition, magnesium nitrate-ammonium nitrate melts, microscopy and microanalysis techniques

\section{Introduction}

Over the past decade, a great deal of effort has been focused on the ratio of magnesium alloys mass and strength $[1,2]$. Magnesium alloys as materials with low density and high strength-to-mass ratio, good fatigue, and impact strength have a wide application prospects in the automotive industry, aerospace, electronic engineering, as well as in electrode components for chemical power sources and rechargeable magnesium battery systems [3-5]. Recently, it has been shown that magnesium alloys, due to their outstanding biocompatibility and biodegradability [6], can be used in the fabrication of biodegradable implants.

Magnesium alloys are presently accounting for only $1 \%$ of the total market for light metal castings. On the other hand, electrodeposition of magnesium and its alloys as a highly efficient production, including innovative processing of Mg-alloys, could become a key factor in cost saving initiatives [7]. However, the electrodeposition of $\mathrm{Mg}$ and $\mathrm{Mg}$-based alloys from aqueous solutions is impossible, because hydrogen is generated at the working cathode before magnesium can be deposited. This prevents even the smallest amounts of magnesium metal to remain as a deposit on an electrode without being dissolved in the aqueous solution. In addition, $\mathrm{Mg}$ cannot be deposited from solutions of simple $\mathrm{Mg}$ salts such as $\mathrm{Mg}\left(\mathrm{ClO}_{4}\right)_{4}$ in conventional organic solvents (acetonitrile, propylene carbonate or dimethylformamide). This is most likely due to the working electrode surface becoming covered by passivating surface films whose ionic conductivity is very low $[3]$.

The electrodeposition of $\mathrm{Mg}$ is done from melts. Some of these melts include inorganic and organic chloride or fluoride salts, combined with cations of some alkaline/alkaline earth metal, or some organic cation or anion [8-11]. Ionic liquids (made of organic salts) became known relatively recently and proved to be suitable media for electrodeposition of metals and alloys at relatively low temperatures (from 273 to $373 \mathrm{~K})[8,12]$.

The melts of alkaline and alkaline earth metals nitrate salts, including their possible application as electrolytes [13-15], became a subject of interest in the second half of the twentieth century [16-18]. Among

*Corresponding author: tel.: +381 621796815; fax: +381 113640230; e-mail address: matori47@hotmail.com 
some nitrate melts investigated electrochemically, neither magnesium nitrate nor magnesium nitrate - ammonium nitrate mixture melts were studied. The data referencing electrodeposition of magnesium, magnesium underpotential deposition and alloy formation from nitrate melts are practically nonexistent, although their working temperatures should be much lower than in other suitable inorganic melts.

Among reasons for nitrate melts not being investigated very often for metal electrodeposition are very pronounced oxidative characteristics of nitrates and a great number of oxidation/reduction processes that can take place between cations and anions and water which is typically present in nitrates $[14,15]$, make these melts not conducive for metal electrodeposition. Magnesium nitrate hexahydrate is an octahedral complex with magnesium cation $\left[\mathrm{Mg}\left(\mathrm{H}_{2} \mathrm{O}\right)_{6}\right]^{2+}$ which is very stable. However, it is impossible to remove water from it by heating, because it decomposes before losing water and transforms into magnesium (II) oxide. Finally, the presence of water in magnesium melts cancels the advantages the melts have against magnesium aqueous solutions. Nitrates also pose additional difficulties related to maintaining the intended temperature at $\pm 3 \mathrm{~K}$, which arise from the large latent heats of the numerous nitrates phase transformations in the temperature range from 373 to $500 \mathrm{~K}$ [16].

Metal electrodeposited under underpotential deposition (UPD) conditions (electrodeposition of metals on foreign substrates at potentials more positive than the equilibrium potential of the depositing metal) from aqueous, non-aqueous solutions and melts (even at room temperatures) onto a cathode of a different metal can diffuse into the substrate and generate alloys [19-25]. Alloys obtained by overpotential electrochemical deposition (OPD) and UPD can have different chemical and phase structures from the alloys of the same composition obtained by metallurgical (thermal) methods [8, 20-25]. Recently, magnesium/platinum alloys formation by electrochemical means has been the subject of interest because of their applications in chemical power sources, jewelry and prosthetic aids $[3,4,5,6,26-30]$.

In this article, we focus on overcoming the limitations of working on electrodeposition from nitrate melts, establishing whether underpotential deposition of magnesium onto platinum from magnesium nitrate exists, and determining whether it leads to magnesium-platinum alloy formation.

\section{Experimental procedures}

The electrochemical experiments were carried out in a three-electrode electrochemical cell [24, 25] made of Pyrex glass placed in a heating mantle designed for work with melts under a purified argon atmosphere
(99.99\% Ar). The temperature of the melts was controlled (via electronic thermostat) between 363 and $463 \mathrm{~K} \pm 3 \mathrm{~K}$. Central neck was closed with a Teflon plug carrying the working electrode $(99.999 \%$ Pt plate $0.4 \mathrm{~cm}^{2}$ ), left neck with a Teflon plug holding an argon glass inlet-outlet and glass Luggin capillary with magnesium reference electrode (3 mm diameter $99.999 \%$ $\mathrm{Mg}$ wire), and right neck with Teflon plug holding magnesium anode $(99.999 \% \mathrm{Mg})$ in the shape of a curved rectangular shovel $\left(7.5 \mathrm{~cm}^{2}\right.$ active surface area) and a tube of thin glass with a thermocouple. Argon and other possible gases coming out of the cell were captured/washed in two bottles (first with a slightly basic solution and second with a slightly acid solution). The cell setup was placed into a sealed transparent plastic "glove box" to create a moisture free atmosphere around the cell.

The melt used in this work was a non-aqueous eutectic mixture $\mathrm{Mg}\left(\mathrm{NO}_{3}\right)_{2}+\mathrm{NH}_{4} \mathrm{NO}_{3}$. The preparation process of the non-aqueous eutectic mixture $\mathrm{Mg}\left(\mathrm{NO}_{3}\right)_{2}+\mathrm{NH}_{4} \mathrm{NO}_{3}$ has been described in detail elsewhere and briefly stated below $[24,25]$. The process of water removal from magnesium nitrate hexahydrate included: $5 \mathrm{~g}$ of magnesium nitrate hexahydrate and $15 \mathrm{~cm}^{3}$ of trimethyl orthoformate brought to a boil and kept for $90 \mathrm{~min}$ under reflux at $343 \mathrm{~K}$, followed after $90 \mathrm{~min}$ by formation of crystals of non-aqueous magnesium nitrate and remaining liquid being submitted to a vacuum distillation at $343 \mathrm{~K}$. Upon removal of the visible liquid the remaining crystals were vacuum dried for additional $60 \mathrm{~min}$. Non-aqueous magnesium nitrate was kept in a closed glass container in a desiccator furnished with plenty of silica gel. Ammonium nitrate hexahydrate was dried for ten hours at $378 \mathrm{~K}$. Wanted amounts of magnesium nitrate mixture with ammonium nitrate were placed into the cell supplied with electrodes, argon supply was turned on, and the system was heated gradually to the wanted temperature.

Before each measurement, the electrodes, a platinum working electrode, magnesium anode, and a reference electrode were mechanically polished with emery paper (FEPA P-4000) to a mirror finish and then etched. Platinum working electrode (99.999\% $\mathrm{Pt}$ ) was etched in aqua regia in several intervals of ten seconds alternating with washing with deionized water. Magnesium anode and a reference electrode were etched in the solution, made of conc. $\mathrm{HNO}_{3}+$ conc. $\mathrm{H}_{2} \mathrm{SO}_{4}+$ deionized water, in several intervals of ten seconds alternating with washing with deionized water [24]. Finally, all electrodes were rinsed with deionized water, absolute ethyl alcohol, dried and mounted in the cell.

The experiments involved using electrochemical techniques: linear sweep voltammetry (LSV) and potential step. The potentials of working electrodes were measured in relation to the equilibrium potential of 

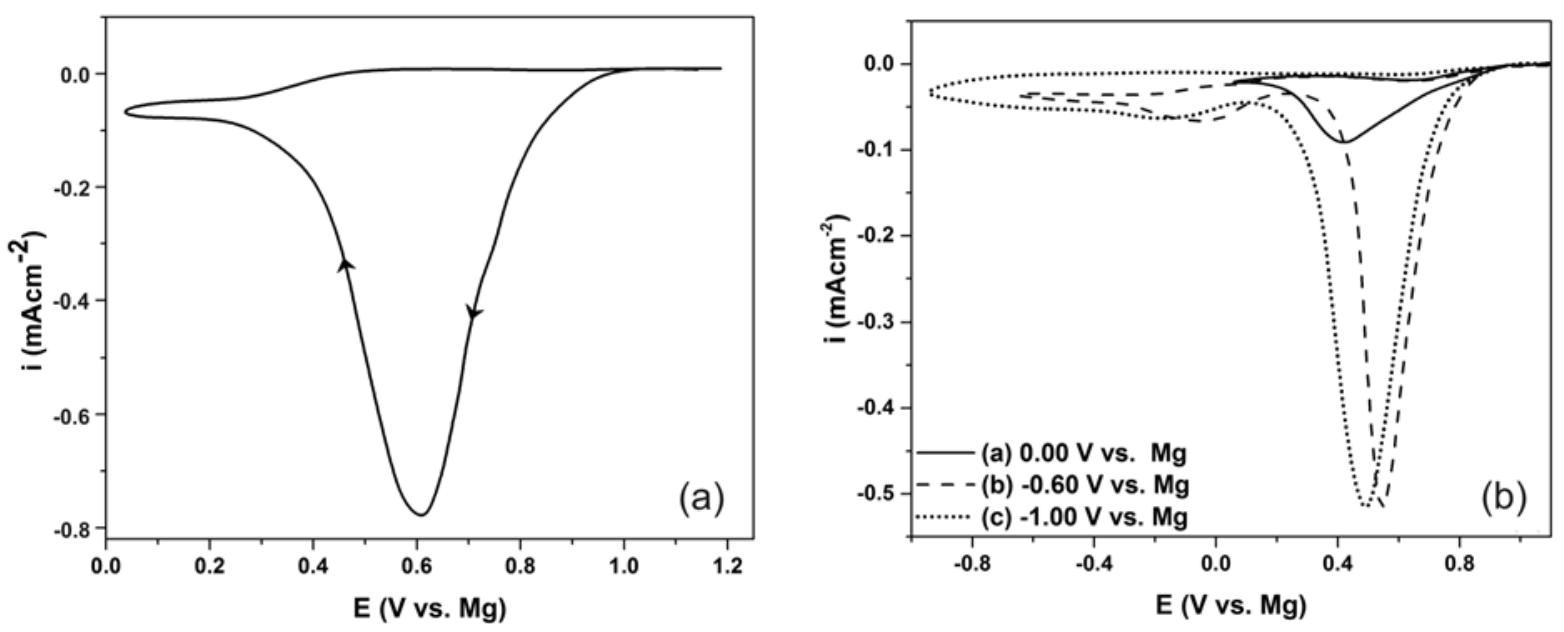

Fig. 1. Cyclic voltammograms recorded on a Pt electrode in non-aqueous eutectic mixture $\mathrm{Mg}\left(\mathrm{NO}_{3}\right)_{2}+\mathrm{NH}_{4} \mathrm{NO}_{3}$ at $450 \mathrm{~K}$, obtained with scan rate $40 \mathrm{mV} \mathrm{s}^{-1}$; a) $E_{\mathrm{s}}=+1.200 \mathrm{~V} \leftrightarrow 0.050 \mathrm{~V}$ vs. $\mathrm{Mg}$ and b) - ) $E_{\mathrm{s}}=+1.100 \mathrm{~V} \leftrightarrow 0.000 \mathrm{~V}$ vs. $\mathrm{Mg}$; $---) E_{\mathrm{s}}=+1.200 \mathrm{~V} \leftrightarrow-0.600 \mathrm{~V}$ vs. $\left.\mathrm{Mg} ; \cdots\right) E_{\mathrm{s}}=+1.200 \mathrm{~V} \leftrightarrow-1.000 \mathrm{~V}$ vs. $\mathrm{Mg}$.

magnesium reference electrode in the melt used under given conditions.

The cyclic voltammetry experiments included one or more cycles of the working electrode potential cycling from a starting potential, $E_{\mathrm{S}}$ (usually 50 to $100 \mathrm{mV}$ more negative than the reversible potential of Pt working electrode) to a final potential, $E_{\mathrm{F}}$ (which was positive to the reversible potential of $\mathrm{Mg}$ ) and then back again to $E_{\mathrm{S}}$, all at scan rates (between 5 and $100 \mathrm{mV} \mathrm{s}^{-1}$ ). Results were recorded by Potentiostat/Galvanostat Princeton Applied Research Corporation Model 273A and controlled by Power Suite Software (Princeton Applied Research).

The potential step method included a change of the working electrode potential from an initial potential, $E_{\mathrm{I}}$ (50 to $100 \mathrm{mV}$ more negative to platinum equilibrium potential in the given melt) to a potential, $E_{\mathrm{X}}$ (50 to $100 \mathrm{mV}$ more positive to magnesium equilibrium potential in the given melt). $E_{\mathrm{X}}$ potential was held constant for 120 and $600 \mathrm{~min}$, after that the cathode was retrieved from the cell under potential to preserve deposited material or possible alloys formed during UPD of magnesium.

After undergoing UPD on platinum, the electrodes were thoroughly washed in the glove box with the absolute ethyl alcohol to remove the melt residue. Then, the sample was transferred out of the box and kept without exposure to the atmosphere. Thus obtained samples were characterized by Scanning electron microscope (SEM) with an Energy dispersive spectroscopy (EDS) (SEM - "JEOL", model JSM-5800, Japan, EDS - "Oxford INCA 3.2", U.K.) and energy dispersive X-Ray spectroscopy (EDX-mapping - Oxford IncaEnergy EDX), X-Ray diffraction using (XRD - "Enraf Nonius powder diffractometer", Germany), Atomic force microscopy (AFM with NanoScope 3D Veeco, USA).

\section{Results and discussion}

In this work, it was essential to confirm that the method of water removal from magnesium nitrate described above had been effective. It was found that the mass difference between the magnesium nitrate hexahydrate entering the process of water removal and the magnesium nitrate leaving the said process was $39 \pm 3 \%$. This would suggest that at least $92 \%$ of water had been removed. The deviation from $100 \%$ can be attributed to the residual methanol, methyl ester of formic acid or some of their derivatives because the obtained $\mathrm{Mg}\left(\mathrm{NO}_{3}\right)_{2}$ crystals appeared to give off these chemicals immediately after drying. In addition, earlier obtained results suggest that the process of water removing from magnesium nitrate hexahydrate was successful [24].

There is no universal reference electrode in experiments with melts. Therefore, in the systems where underpotential deposition is examined it is common practice to use the reversible potential of the depositing metal as a reference electrode potential with an ascribed value of $0.000 \mathrm{~V}$. In the nitrate melts used, for magnesium underpotential deposition on platinum, this meant using magnesium as a reference electrode. Polarization measurements and cyclic voltammetry performed on the magnesium working electrode with magnesium reference, and counter electrodes have shown that reversible magnesium potential in the used magnesium nitrate melts, under temperatures ranging from 340 to $500 \mathrm{~K}$, was stable [25]. The experiments in the non-aqueous eutectic $\mathrm{Mg}\left(\mathrm{NO}_{3}\right)_{2}+\mathrm{NH}_{4} \mathrm{NO}_{3}$ mixture were performed at $450 \mathrm{~K}$ and reversible potential of polycrystalline platinum was $1.290 \mathrm{~V} \pm 30 \mathrm{mV}$ vs. $\mathrm{Mg}$.

Typical examples of the voltammograms obtained in our system are given in Figs. 1a,b. General charac- 
teristics of the voltammograms indicated the presence of more than one reduction peak with no oxidation counterparts. Stripping peaks were not observed even when cathodic end potential was pushed into overpotential range. Sometimes reduction peaks were spread over a wider range of applied potentials without showing a steeper increase or decrease of current density values. Such structures of voltammogram peaks are characteristic of multiple processes which start successively one after the other at potentials whose values are close and proceed further simultaneously (often next process starts with increasing rate at the same time that a previous process ends with a diminishing rate). The obtained peaks then represent the sum of rates of all the processes taking part at a certain potential. The absence of anodic (oxidation) counterparts to the cathodic peaks was a subject of some works $[14,15,23,31-33]$. These studies emphasize that in nitrate melts changes of the platinum electrode potential from anodic to cathodic values (compared to the magnesium reversible potential) provoke passivation of the working electrode surface which becomes partially (or fully) covered with magnesium oxides layers. These layers do not dissolve when the potential is returned to the starting value.

Suggestions of the possible processes that could produce reduction peaks in the magnesium UPD region investigated, apart from ones brought about by the magnesium underpotential deposition itself, can be found in rare published works $[14,15]$. It is important to point out that the potentials of the proposed reactions measured relative to $\mathrm{Na}, \mathrm{K}$ or $\mathrm{Li}$, cannot be directly used in our case, but it can be assumed with enough certainty that the order of the reaction potentials and the potential differences between these processes were preserved with respect to magnesium reference potential. However, absolute values must be changed by the amounts reflecting differences in reference potentials between $\mathrm{Na}, \mathrm{K}$, and $\mathrm{Li}$ in their nitrate melts and $\mathrm{Mg}$ in used nitrate melts.

Results obtained with linear sweep voltammetry have shown, as it was expected $[14,15,24]$, that the first group of anion (nitrate) reduction processes from the non-aqueous nitrate melt used proceed at potentials between $\approx 850$ and $350 \mathrm{mV}$ vs. $\mathrm{Mg}$, followed by the second group of nitrate reduction processes at potentials more negative than $350 \mathrm{mV}$ vs. $\mathrm{Mg}[14,15$, $24]$ but still in magnesium UPD range. The said reaction potentials are mutually very close, and therefore, the current peaks were smeared over the recorded potential range. The change of the platinum electrode potential from positive values to the magnesium reversible potential (magnesium UPD region), induces some reactions based on nitrogen-based anions and cation, very reactive oxygen anion $\mathrm{O}^{2-}, \mathrm{OH}^{-}$and sometimes water [24] also. All produced gases were removed from the electrochemical cell by the argon stream, so when the electrode potential is reversed into a positive direction, the theoretically possible reverse oxidation reaction back to initial $\mathrm{NO}_{3}^{-}$or $\mathrm{H}_{2} \mathrm{O}$ could no longer be expected. As a result, no anodic voltammogram peaks due to the oxidation of the produced gases could be recorded. Furthermore, $\mathrm{O}^{2-}$ produced in inner and outer parts of the electrochemical double layer very quickly engaged in reaction with $\mathrm{Mg}^{2+}$ present $[14,15,23,24,31-33]$ :

$$
\mathrm{Mg}^{2+}+\mathrm{O}^{2-} \rightarrow \mathrm{MgO}
$$

the result being the formation of insoluble magnesium oxides in the magnesium UPD region. The thermal decomposition constant $[14,15]$ decides upon the stability of possibly present magnesium hydroxide:

$$
\mathrm{Mg}(\mathrm{OH})_{2} \leftrightarrow \mathrm{MgO}+\mathrm{H}_{2} \mathrm{O}
$$

In the melt made of a eutectic mixture of magnesium nitrate and ammonium nitrate, at the temperatures used, ammonium ion, resulting from $\mathrm{NH}_{4} \mathrm{NO}_{3}$ dissociation $[14,15]$, forms a compound $\left(\mathrm{NH}_{4}\right)_{3}$ $\mathrm{Mg}\left(\mathrm{NO}_{3}\right)_{5}$. In the melt, this compound exists as a quasi-crystalline structure made of $\mathrm{NH}_{4}^{+}, \mathrm{Mg}^{2+}$ cations, and $\mathrm{NO}_{3}^{-}$anions $[14,15]$. The fact that the reduction current densities in the magnesium nitrate melts increase with the increase of the ammonium nitrate present, at the constant temperature in the magnesium UP region investigated, leads to the conclusion that $\mathrm{NH}_{4}^{+}$reduction is taking place:

$$
2 \mathrm{NH}_{4}^{+}+2 \mathrm{e}^{-} \rightarrow 2 \mathrm{NH}_{3}+\mathrm{H}_{2} \text {. }
$$

However, this reaction is, under conditions given, irreversible and voltammograms could not show oxidation peaks when the electrode potential was reversed in the positive direction.

From the above data, it can be concluded that in the UPD region examined anodic voltammogram peaks cannot be expected.

The half of the work function difference between $\mathrm{Pt}$ substrate and depositing $\mathrm{Mg}$ is $\approx 450 \mathrm{eV}$ [34] and according to [35] the UPD of magnesium onto platinum should be almost certain. It is logical to assume then that the reduction peaks obtained by LSV measurements on the platinum working electrode from magnesium nitrate and ammonium nitrate melt used in the magnesium underpotential region are sums of partial current densities for $\mathrm{Mg}^{2+}$ underpotential reduction, nitrate anion reduction, and ammonium cation reduction. Being a sum, the recorded current densities suggest small magnesium underpotential deposition of partial current densities. Such small current densities exhibited by the UPD voltammograms from similar melts $[23,32$, $36,37]$ were characteristic of deposited metal mono- 

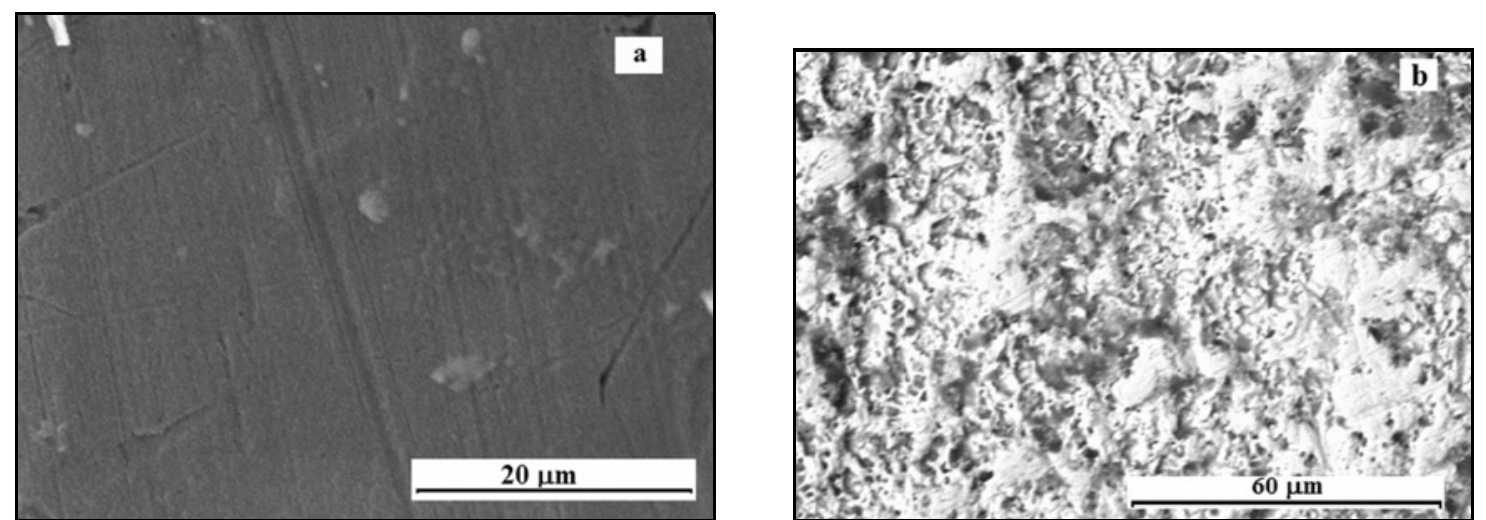

Fig. 2. SEM micrographs of $\mathrm{Pt}$ surface after magnesium underpotential deposition at $450 \mathrm{~K}$ from non-aqueous eutectic mixture $\mathrm{Mg}\left(\mathrm{NO}_{3}\right)_{2}+\mathrm{NH}_{4} \mathrm{NO}_{3}$ by using potentiostatic technique for a) $2 \mathrm{~h}$ and b) $5 \mathrm{~h}$.

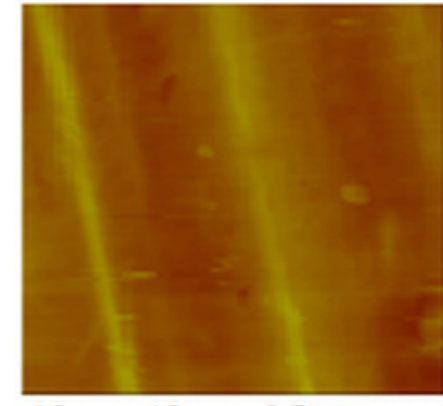

$10 \mu \mathrm{m} \times 10 \mu \mathrm{m} \times 0.7 \mu \mathrm{m}$ RMS $=38.328 \mathrm{~nm}$

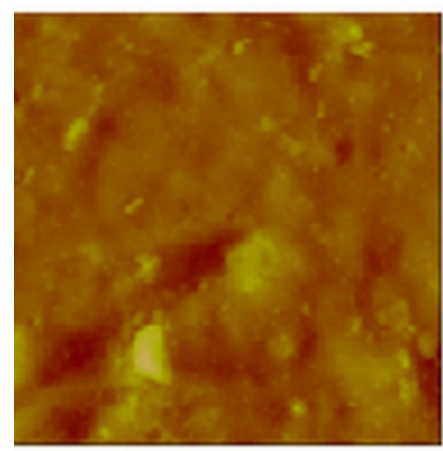

$50 \mu \mathrm{m} \times 50 \mu \mathrm{m} \times 2.5 \mu \mathrm{m}$

$\mathrm{RMS}=109.69 \mathrm{~nm}$

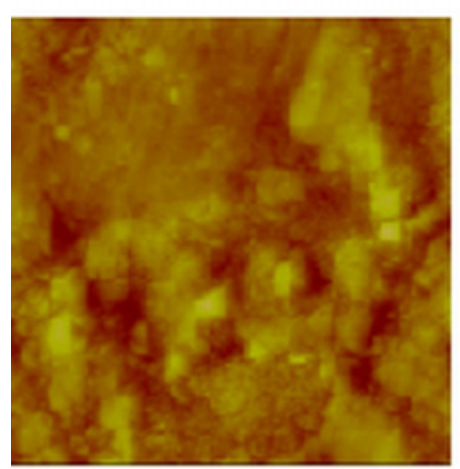

$50 \mu \mathrm{m} \times 50 \mu \mathrm{m} \times 4 \mu \mathrm{m}$ $\mathrm{RMS}=354.78 \mathrm{~nm}$ a)

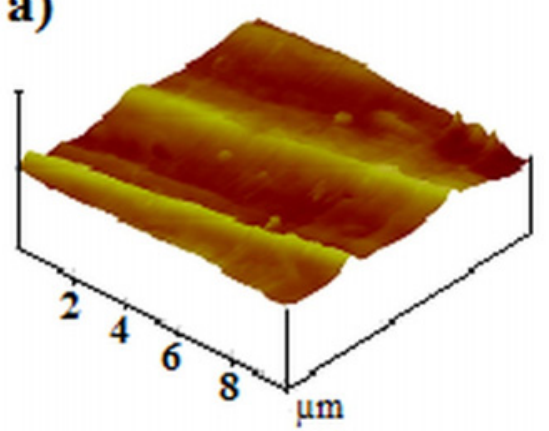

b)

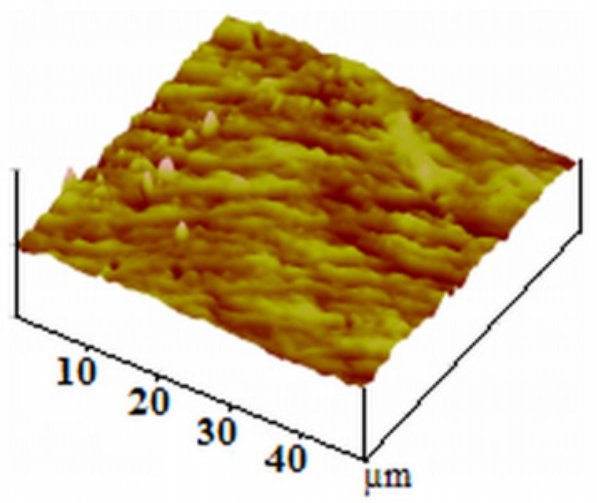

c)

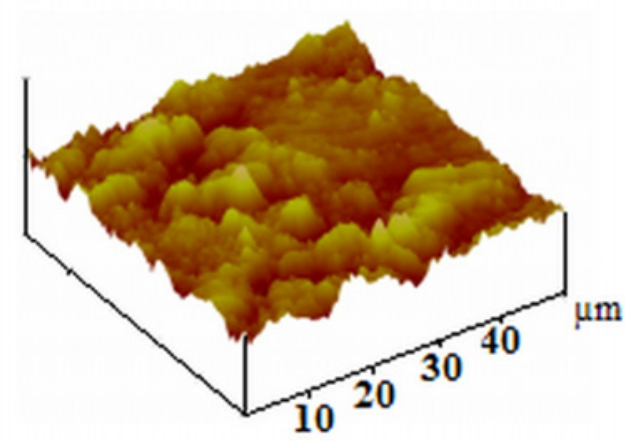

Fig. 3. 2D and 3D AFM images of the platinum surface: a) before magnesium underpotential deposition and after magnesium underpotential deposition at $450 \mathrm{~K}$ for b) $2 \mathrm{~h}$ and c) $5 \mathrm{~h}$. 
Table 1. Results of EDS semi-quantitative analysis for the Pt samples exposed to the constant potential of +60 to $+100 \mathrm{mV}$ vs. $\mathrm{Mg}$ for 2 and $5 \mathrm{~h}$ in used melts

\begin{tabular}{lcccc}
\hline \multicolumn{5}{c}{$2 \mathrm{~h} \mathrm{Mg} \mathrm{UPD}$ on Pt substrate } \\
\hline Elmt. & Spec Type & Elmt ( \%) & Sgma (\%) & $($ at. \%) \\
\hline O K & ED & 30.53 & 0.14 & 6.60 \\
Mg K & ED & 1.11 & 0.03 & 1.56 \\
Pt M & ED & 68.36 & 0.27 & 1.84 \\
Total & & 100.0 & & 3.79 \\
\hline & & $5 \mathrm{~h} \mathrm{Mg} \mathrm{UPD} \mathrm{on} \mathrm{Pt} \mathrm{substrate}$ & 7.95 \\
O K & ED & 23.40 & 0.47 & 8.26 \\
Pg K & ED & 3.03 & 0.04 & 100.0 \\
Total & ED & 73.56 & 0.25 & \\
\hline
\end{tabular}
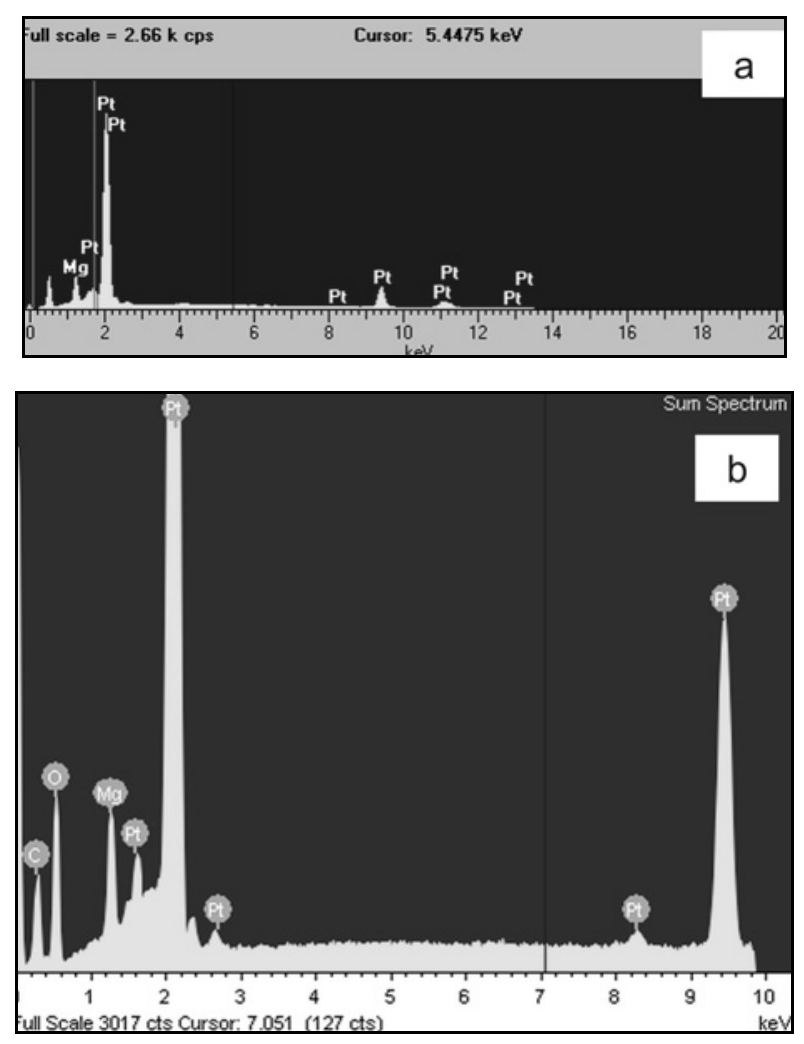

Fig. 4. Characteristic EDS spectra of platinum samples after a) $2 \mathrm{~h}$ and b) $5 \mathrm{~h}$ of magnesium underpotential deposition at $450 \mathrm{~K}$.

layers diffusing into the substrate and forming alloys.

The indication of magnesium underpotential deposition on platinum is exhibited in Figs. 2-5. They represent SEM, AFM, EDS, and EDX results obtained from the platinum electrode held for two and five hours on electrode potential of $+60 \mathrm{mV}$ vs. $\mathrm{Mg}$ in the non-aqueous eutectic mixture $\mathrm{Mg}\left(\mathrm{NO}_{3}\right)_{2}+\mathrm{NH}_{4} \mathrm{NO}_{3}$ at $T=450 \mathrm{~K}$. A typical example of XRD analysis results for the platinum sample exposed to magnesium underpotential deposition at $+80 \mathrm{mV}$ vs. $\mathrm{Mg}$ in the same melt and at $T=450 \mathrm{~K}$ for: a) $2 \mathrm{~h}$ and b) $5 \mathrm{~h}$ is shown in Figs. 6a,b. In this particular case, the results obtained using XRD analyses suggest that magnesium-platinum alloys are being formed.

The surface of the platinum sample taken after magnesium underpotential deposition at $450 \mathrm{~K}$ for two and five hours was analysed by SEM (Fig. 2) and AFM (Fig. 3). The deposits are very compact and significantly rough with agglomerations of different sizes. The roughness and height of the agglomerations increase slightly with increased deposition time.

In Fig. 3a sporadic small areas of rough morphology, probably caused by mechanical interaction during polishing, could be seen on flat and uniform bare platinum surface. The 2D and 3D images in Figs. 3b,c obtained after two and five hours, respectively, of $\mathrm{Mg}$ UPD showed crystalline agglomerations, which seem to have a form of islands.

The results obtained by EDS (Figs. 4a,b and Table 1), EDX (Figs. 5a,b) and XRD (Figs. 6a,b and Table 2) analysis of the $\mathrm{Pt}$ substrates exposed to constant potentials in the magnesium underpotential region ( +50 to $+150 \mathrm{mV}$ vs. $\mathrm{Mg}$ ) strongly suggest that magnesium deposition takes place at potentials more positive than the equilibrium potential of the depositing metal and magnesium-platinum alloys being formed.

It is impossible to identify the precise value of the potential at which magnesium UPD starts. However, it is obviously significantly positive to the reversible magnesium potential in the used melt.

According to the Hume/Rothery rules [38], Mg and $\mathrm{Pt}$ fulfill the required conditions to form alloys (solid solutions), including "the $15 \%$ rule", because $\mathrm{Mg}$ and $\mathrm{Pt}$ atomic radii differ only by $10 \%$. However, it has been pointed out [26, 44], the phase diagram 


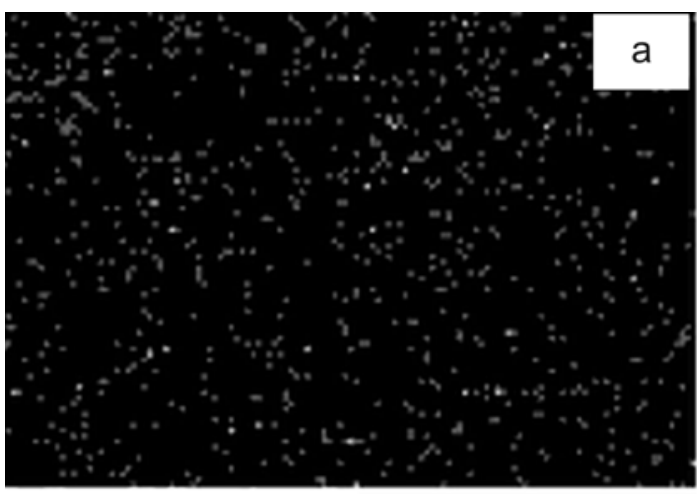

Mg Ka1_2

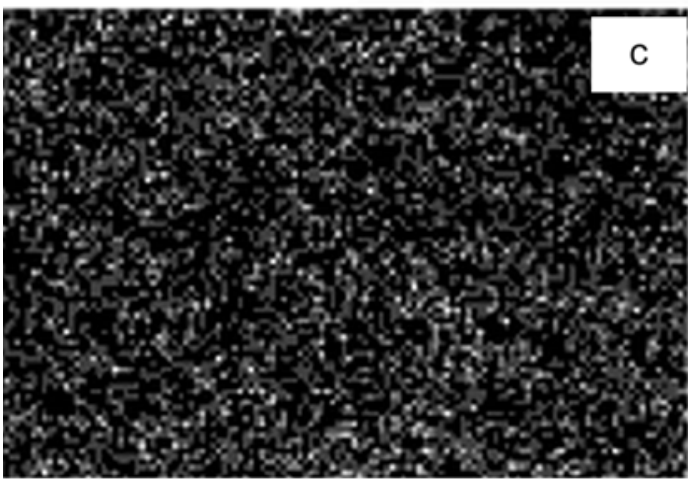

Mg Ka1_2

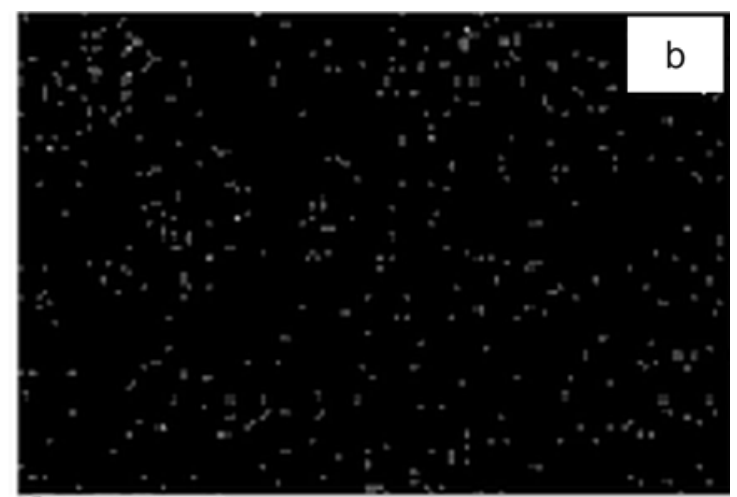

O Ka1

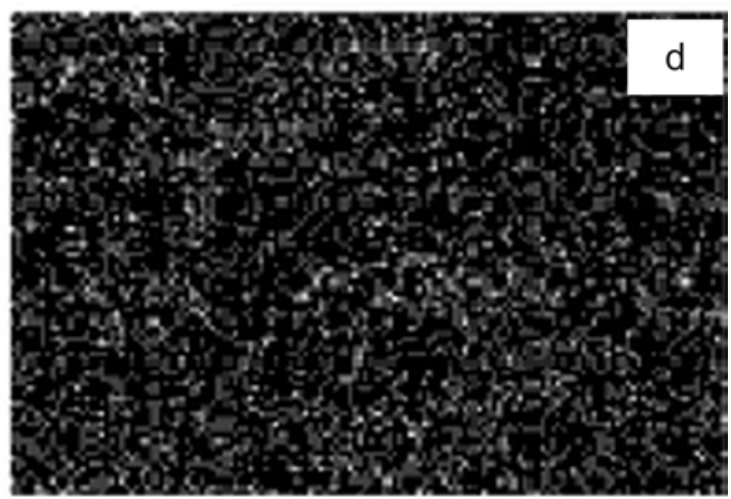

O Ka1

Fig. 5. EDX maps of magnesium a), c) and oxygen b), d) distribution images after two and five hours of magnesium underpotential deposition at $450 \mathrm{~K}$.
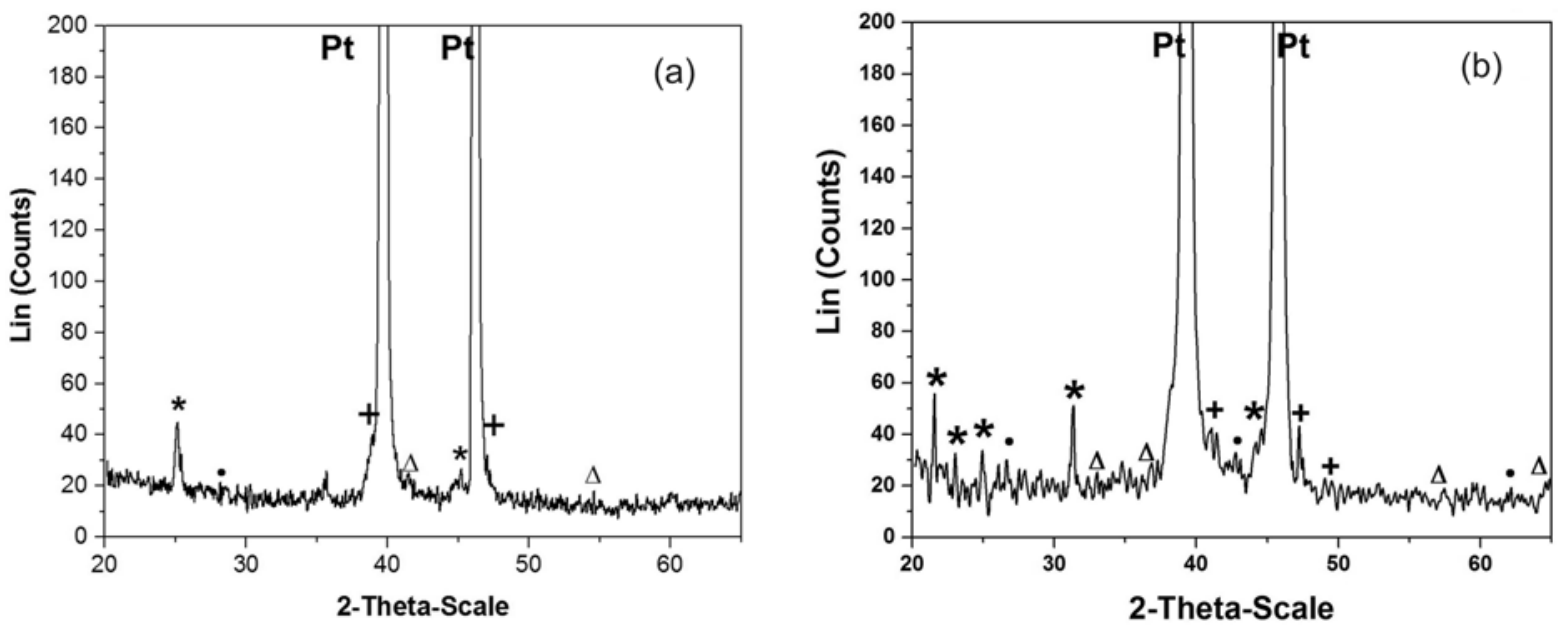

Fig. 6. Diffraction patterns of platinum sample after a) two and b) five hours of magnesium underpotential deposition at $E_{\mathrm{X}}=+80 \mathrm{mV}$ vs. $\mathrm{Mg}$ in non-aqueous eutectic mixture $\mathrm{Mg}\left(\mathrm{NO}_{3}\right)_{2}+\mathrm{NH}_{4} \mathrm{NO}_{3}$ at $T=450 \mathrm{~K}$; a $)$ and b) (+) (fct) $\mathrm{MgPt}_{3}[39] ;(*)(\mathrm{hcp})-\mathrm{Mg}_{3} \mathrm{Pt}[40] ;(\Delta)$ (bcc) - $\mathrm{MgO}_{2}$ [41]; (•) - (fcc) $\mathrm{MgO}$ [42].

has not been completely determined for the $\mathrm{Mg}-\mathrm{Pt}$ system.

The solubility of $\mathrm{Pt}$ in $\mathrm{Mg}$ appears to be negligible, and that of $\mathrm{Mg}$ in $\mathrm{Pt}$ has not been determined. However, the conductivity of a two-phase $\mathrm{Mg}-0.14$ at.\%-Pt alloy was measured, and it proved that the conductiv- ity was less than that of pure $\mathrm{Mg}$, so there was some solubility of $\mathrm{Pt}$ in $\mathrm{Mg}$ [44]. On the other side of the diagram the X-ray analysis of a two-phase $\mathrm{Mg}-\mathrm{Pt}$ alloy (Mg-0.12 at.\%-Pt), and the lattice parameters of $\mathrm{Mg}$ ( $a=0.32080 \mathrm{~nm}$ and $c=0.52103 \mathrm{~nm}$ ) and those of pure $\operatorname{Mg}(a=0.32088 \mathrm{~nm}$ and $c=0.52099 \mathrm{~nm})$ shows 
Table 2. The alloys identified on platinum samples after magnesium underpotential deposition at different times from non-aqueous eutectic mixture $\mathrm{Mg}\left(\mathrm{NO}_{3}\right)_{2}+\mathrm{NH}_{4} \mathrm{NO}_{3}$ at $T=450 \mathrm{~K}$

\begin{tabular}{ccccc}
\hline$T(\mathrm{~K})$ & Time $(\mathrm{h})$ & Identified phase & System & Approximate composition (at.\% Pt) \\
\hline 450 & 2 & $\mathrm{MgPt}_{3}$ & hcp & $\approx 71.6$ \\
\hline 450 & 5 & $\mathrm{MgPt}_{3}$ & fct & $\approx 71.6$ \\
& 5 & $\mathrm{Mg}_{3} \mathrm{Pt}$ & hcp & $\approx 25$ \\
\hline
\end{tabular}

to be very close to each other, indicating a very low solid solubility of $\mathrm{Pt}$ in $\mathrm{Mg}$. An analysis of $\mathrm{Mg}-\mathrm{Pt}$ binary system [44] suggests that the eutectic point is at 7.6 at. $\% \mathrm{Pt}$ and $648 \mathrm{~K}$ (analogous to the Mg-Au system), and "at least" two intermediate phases: a homogeneous solid solution around the $\mathrm{Mg}_{6} \mathrm{Pt}$ composition, and a stoichiometric $\mathrm{Mg}_{3} \mathrm{Pt}$ compound (analogous to the $\mathrm{Mg}-\mathrm{Pd}$ system).

Some authors [26] proposed that the experimental phases at compositions $\mathrm{MgPt}_{7}$ and $\mathrm{Mg}_{85} \mathrm{Pt}_{7}$ were not evaluated because the structures have not been completely determined. At compositions $\mathrm{Mg}_{2} \mathrm{Pt}$ and $\mathrm{MgPt}_{2}$, phases may exist where none has been experimentally observed. While the $\mathrm{MgPt}_{2}\left(\mathrm{Ga}_{2} \mathrm{Hf}\right.$ structure) is found slightly above the tie line $(\sim 1.9 \mathrm{meV})$, the $\mathrm{C} 16$ structure is stable at $\mathrm{Mg}_{2} \mathrm{Pt}$. It is interesting to note, however, that an identical ordering of the phases in composition $\mathrm{Mg}_{3} \mathrm{Pt}$ occurs in the chemically similar Mg-Pd system and that the stable ab initio and experimental phase at composition $\mathrm{MgPd}$ are L10.

Other authors [43] reported that magnesium platinum alloys were prepared by heating $\mathrm{Mg}$ and $\mathrm{Pt}$ in sealed Fe crucibles, then examined metallographically. From these examinations and a few thermal analyses, there were reports [44] of the existence of "at least" two intermediate phases: a homogeneous solid solution around the $\mathrm{Mg}_{6} \mathrm{Pt}$ composition, and a stoichiometric $\mathrm{Mg}_{3} \mathrm{Pt}$ compound (analogous to the $\mathrm{Mg}-\mathrm{Pd}$ system). Different works [42] discovered two more intermediate phases, a MgPt compound and an ordered fct phase near 75 at.\% Pt that coexists with $\mathrm{Pt}$. On the Pt-rich side of the system, two cubic superlattice phases, $\mathrm{MgPt}_{3}$ and $\mathrm{MgPt}_{7}$ were found [45]. The alloys were prepared by reduction of $\mathrm{MgO}$ with $\mathrm{H}_{2}$ in the presence of $\mathrm{Pt}$ between 1373 and $1673 \mathrm{~K}$. $\mathrm{MgPt}_{3}$ was prepared at $1373 \mathrm{~K}$ in the composition range 71.6 to 75.5 at.\% $\mathrm{Pt}$ and $\mathrm{MgPt}_{7}$ was formed in the temperature range 1473 to $1673 \mathrm{~K}$ in the composition range 85.5 to 89.7 at.\% Pt [44]. It appears that the ordered fct phase near 75 at.\% Pt reported by [39] and the ordered $\mathrm{MgPt}_{3}$ phase of [45] are the same phases.

The alloys: hcp $\mathrm{MgPt}_{3}$ and hcp $\mathrm{Mg}_{3} \mathrm{Pt}$, described in the above-cited literature, have been recorded in magnesium underpotential deposition experiments performed on platinum in used nitrate melts but at temperatures which are several hundred K lower (see Figs. 6a,b and Table 2). Which part of the magne- sium adatoms formed by underpotential deposition on platinum surface participate in oxide formation and which diffuse into the substrate and contribute to alloy formation could not be concluded by linear sweep voltammetry, EDS or XRD results. LSV results indicated EDS and XRD results confirmed both magnesium-platinum alloy and magnesium oxide formation at the surface of the platinum electrode in nitrate melts used.

Equation (1) describes the process of magnesium oxide formation in the absence of water in the used melts $[14,15]$. In addition, some novel results [3133 ] suggest that every amount of reactive magnesium on the electrode surface in the presence of $\mathrm{O}^{2-}$ and $\mathrm{OH}^{-}$anions very quickly turns into $\mathrm{MgO}$. Therefore, the surface of the platinum working electrode becomes partially covered with $\mathrm{MgO}$ even in the first linear change of the potential from anodic end to cathodic end of the magnesium underpotential range. This, however, did not preclude a sufficient amount of magnesium underpotentially produced adatoms to participate in magnesium-platinum alloy formation by interdiffusion. Part of the magnesium ions in magnesium (II) oxide probably diffuse through the oxide layer to the platinum surface where they become discharged into magnesium adatoms which are then participating in the interdiffusion processes as well. Fast and unavoidable formation of insoluble $\mathrm{MgO}$ in the magnesium underpotential deposition range on platinum from used nitrate melts explains quasi-passivation of the working electrode and the lack of anodic current peaks on the voltammograms recorded.

\section{Conclusions}

The UPD of Mg on Pt substrate from magnesium nitrate melts used at potentials very close to $100 \mathrm{mV}$ vs. Mg was established.

As a result of the magnesium underpotential deposition onto the platinum substrate from the nitrate melts used the formation of two alloys, $\mathrm{Mg}_{3} \mathrm{Pt}$ and $\mathrm{Pt}_{3} \mathrm{Mg}$, was observed.

Alloys obtained were formed at the temperatures several hundred degrees Kelvin lower than the temperatures which are, according to the existing knowledge 
on the binary Mg-Pt system, needed for their formation by thermal means.

It appears that underpotential deposition of the metals unsuitable for electrodeposition from aqueous electrolytes, like magnesium, can be performed even from nitrate melts at low temperatures and that it can lead to the formation of alloys in a controlled manner.

\section{Acknowledgement}

This work was supported by the Ministry of Education, Science and Technology of the Republic of Serbia (Grant ON 172060).

\section{References}

[1] Rokhlin, L.: In: Advances in Metallic Alloys. Volume 3. Eds.: Fridlyander, J. N., Eskin, D. G. New York, Taylor \& Francis 2003.

[2] Friedman, P. A., Copple, W. B.: J. Mater. Eng. Perform.,13, 2004, p. 335. doi:10.1361/10599490419162

[3] Viestfrid, Y., Levi, M. D., Gofer, Y., Aurbach, D. J.: Electroanal. Chem., 576, 2005, p. 183. doi:10.1016/i.jelechem.2004.09.034

[4] Eliezer, D., Aghion, E., Froes, F. H.: Advance Performance Materials, 5, 1998, p. 201. doi:10.1023/A:1008682415141

[5] D'Errico, F., Kim, S. K., Garces, P. G., Giger, F.: JOM, 65, 2013, p. 1293. doi:10.1007/s11837-013-0705-1

[6] Mezbahul-Islam, M., Mostafa, A. O., Medraj, M.: Journal of Materials, Article ID 704283, 2014. doi:10.1155/2014/704283

[7] Kierzek, A., Adamiec, J.: Archives of Metallurgy and Materials, 56, 2011, p. 759. doi:10.2478/v10172-011-0084-y

[8] Kolb, D. M.: In: Advances in Electrochemical Science and Engineering. Eds.: Alkire, R. C., Kolb, D. M. Weinheim, Wiley-VCH 2001.

[9] Martinez, A. M., Haarberg, G. M., Borresen, B., Castrillejo, Y., Tunold, R.: J. Appl. Electrochem., 34, 2004, p. 1271. doi:10.1007/s10800-004-1761-6

[10] Lu, Z., Schechter, A., Moshkovich, M., Aurbach, D.: J. Electroanal. Chem., 466, 1999, p. 203. doi:10.1016/Soo22-0728(99)00146-1

[11] Wang, P., NuLi, Y., Yang, J., Feng, Z.: Surf \& Coat Techn., 201, 2006, p. 3783. doi:10.1016/j.surfcoat.2006.03.020

[12] Mamantov, G., Hussey, C. L., Marassi, R.: In: Techniques for Characterization of Electrodes and Electrochemical Processes. Eds.: Varma, R., Selamn, J. R. New York, John Wiley and Sons 1991.

[13] Bhatia, K., Sharma, R. C., Gaur, H. C.: Electrochim. Acta, 23, 1978, p. 1367. doi:10.1016/0013-4686(78)80018-8

[14] Tkalenko, D. A.: Electrochemistry of Molten Nitrates. Kiev, Naukova Dumka 1983. (in Russian)

[15] Tkalenko, D. A.: Macrokinetics Cathode Processes Hydroxide and Nitrate Melts. Kiev, Naukova Dumka 1993. (in Russian)
[16] Ramana, K. V., Sharma, R. C., Gaur, H. C.: J. Chem. Engineer. Data, 31, 1986, p. 288. doi:10.1021/je00045a009

[17] Ramana, K. V., Sharma, R. C., Gaur, H. C.: J. Chem. Engineer. Data, 35, 1990, p. 293. doi:10.1021/je00061a020

[18] Ramana, K. V., Sharma, R. C., Gaur, H. C.: J. Chem. Engineer. Data, 35, 1990, p. 418. doi:10.1021/je00062a013

[19] Vidu, R., Hirai, R., Hara, N.: Phys. Chem. Chem. Phys., 3, 2001, p. 3320. doi:10.1039/b010250o.

[20] Radović, B. S., Edwards, R. A. H., Jovićević, J. N.: J. Electroanal. Chem., 428, 1997, p. 113. doi:10.1016/S0022-0728(96)05050-4

[21] Radović, B. S., Cvetković, V. S., Edwards, R. A. H., Jovićević, J. N.: Kovove Mater., 48, 2010, p. 159. doi:10.4149/km_2010_3_159

[22] Radović, B. S., Cvetković, V. S., Edwards, R. A. H., Jovićević, J. N.: Kovove Mater., 48, 2010, p. 55. doi:10.4149/km_2010_1_55

[23] Stafford, G. L., Hussey, C. L.: In: Advances in Electrochemical Science and Engineering. Eds.: Alkire, R. C., Kolb, D. M. Weinheim, Wiley-VCH Verlag GmbH 2002.

[24] Cvetkovic, V. S., Bjelica, L. J., Vukicevic, N. M., Jovicevic, J. N.: CI\&CEQ, 21, 2015, p. 527. doi:10.2298/CICEQ141205009C

[25] Cvetković, V. S.: Underpotential Deposition of Magnesium from Nitrate Melts. Mitrovica, Zadužbina Andrejević - PMF K. 2012. (in Serbian)

[26] Taylor, R. H., Curtarolo, S., Hart, G. L. W.: Physical Review. B84 084101-1/084101-16, 2011. doi:10.1103/PhysRevB.84.084101

[27] Esbenshade, L. J., Barile, J. C., Fister, T. T., Bassett, L. K., Fenter, P., Nuzzo, G. R., Gewirth, A. A.: J. Phys. Chem. C, 119, 2015, p. 23366. doi:10.1021/acs.jpcc.5b07825

[28] Vardar, G., Sleightholme, E. S. A., Naruse, J., Hiramatsu, H., Siegel, J. D., Monroe, W. C.: Appl. Mater. Interfaces, 6, 2014, p. 18033. doi:10.1021/am5049064

[29] Chang, J., Haasch, T. R., Kim, J., Spila, T., Braun, V. P., Gewirth, A. A., Nuzzo, G. R.: ACS Appl. Mater. Interfaces, 7, 2015, p. 2494. doi:10.1021/am507375t

[30] Biggs, T.: Metals Rev., 49, 2005, p. 2. doi:10.1595/147106705X24409

[31] Amir, N., Chusid, O. V., Aurbach, D. G.: J. Power Sources, 174, 2007, p. 1234. doi:10.1016/j.jpowsour.2007.06.206

[32] Martinez, A. M., Borresen, B., Haarberg, G. M., Catrillejo, Y., Tunold, R.: J. Electrochem. Soc., 151, 2004, p. C508. doi:10.1149/1.1758814

[33] Brenner, A.: In: Advances in Electrochemistry and Electrochemical Engineering. Ed.: Tobias, C. W. New York, Interscience 1976.

[34] CRC Handbook of Chemistry and Physics. Boca Raton, CRC Press Inc. 2002.

[35] Kolb, D. M., Przasnyski, M., Gerischer, H.: J. Electroanal. Chem., 54, 1974, p. 25. doi:10.1016/S0022-0728\%2874\%2980377-3

[36] Radović, B. S., Cvetković, V. S., Edwards, R. A. H., Jovićević, J. N.: Int J Mater Res., 102, 2011, p. 59. $\underline{\text { doi: } 10.3139 / 146.110443}$ 
[37] Jovićević, N., Cvetković, V. S., Kamberović, Ž. J., Jovićević, J. N.: Metallurgical and Materials Transactions B, 44, 2013, p. 106.

doi:10.1007/s11663-012-9750-3

[38] Hume-Rothery, W., Smallman, R. E., Haworth, C. W. The Structure of Metals and Alloys. 5th Edition. London, The Institute of Metals 1969.

[39] Stadelmaier, H. H., Hardy, W. K.: Z. Metallkd., 52, 1961, p. 391.

[40] Range, K. J., Haffner, P.: J. Alloys Compd., 183, 1991, p. 430. doi:10.1016/0925-8388(92)90764-Z
[41] Vannerberg, N. G.: Ark. Kemi, 14, 1959, p. 99.

[42] Kondrashev, Y. D., Omel'chenko, Y. A.: Zh. Neorg. Khim., 9, 1964, p. 512.

[43] Ferro, R., Rambaldi, G.: J. Less-Common Metals, 2, 1960, p. 383. doi:10.1016/0022-5088(60)90047-3

[44] Nayeb-Hashemi, A. A., Clark, J. B.: Bulletin of Alloy Phase Diagrams, 6, 1985, p. 533. doi:10.1007/BF02887151

[45] Bronger, W., Klemm, W.: Z. Anorg. Chem., 319, 1962, p. 58. doi:10.1002/zaac. 19623190110 